\title{
SEJARAH LOKAL: MENGENAL YANG DEKAT, MEMPERLUAS WAWASAN
}

\author{
Hariyono \\ Deputi Advokasi UKPPIP, Jakarta
}

\begin{abstract}
Abstrak: Sejarah lokal sebagai salah satu tema sejarah menarik baik dalam proses penelitian maupun pembelajaran di level pendidikan dasar, menengah dan perguruan tinggi. Demikian pula penelitian sejarah lokal dalam tataran akademis hingga pemenuhan kebutuhan praktis hingga sejarah populer, membutuhkan keseriusan dan pendalaman dari kita semua untuk mengemas dan mengembangkannya secara profesional. Hal ini akan berimbas pada suatu pengharapan bahwa masyarakat bukan hanya menjadi penonton dan penikmat masa lampau tetapi juga potensi untuk menjadi pelaku sejarah di masa kini dan masa depan. Penulisan sejarah lokal seyogyanya dibuat lebih komunikatif. Tujuannya agar kisah tersebut juga dapat dipahami oleh masyarakat luas, termasuk masyarakat di daerah tersebut.
\end{abstract}

Kata-kata kunci: sejarah lokal, pelaku sejarah, penulisan sejarah

\begin{abstract}
Local history as a theme of history is interesting for the process of research and teaching in any levels. The study of local history from academic and popular level needs our seriousness and depth to package and to develop professionally. This will affect to a hope that society are not only the audience and past target but also the potential to be the historical actor at present and future. The writing of local history should be more communicative. This aims that the story could be understood easily by the mass society, including the locals.
\end{abstract}

Keywords: local history, historical actor, writing of history

Dalam kehidupan sehari-hari yang dekat tidak selalu dikenal dan dipahami lebih baik. Perkembangan teknologi informasi dan komunikasi membuat ruang dan waktu semakin mampat dan dunia berjalan tunggang langgang. Kita sering lebih cepat tahu "apa yang jauh di sana" dibanding dengan apa yang terjadi di sekitar lingkungan hidup kita. Apa yang terberitakan di belahan dunia yang secara geografis sangat jauh dengan cepat dapat terakses dalam hitungan detik atau menit. Sebaliknya apa yang terjadi di sekitar kita tidak terberitakan secara masif dan intensif. Konsekuensi dari kondisi tersebut informasi yang kita miliki tidak selalu didasarkan pada sumber yang dekat secara geografis, misalnya kadang kita tidak tahu nama ketua RW, lurah atau camat dimana kita tinggal, tetapi kita justru kenal dan familiar dengan presiden nama Presiden Amerika. Kita tidak tahu nama-nama pemain kesebelasan yang mewakili keluharan kita dalam pertandingan antar kelurahan dalam perayaan kemerdekaan Indonesia. Kita justru kenal dan hafal dengan pemain-pemain Barcelona, Real Madrid, Juventus, Chelsea dan sebagainya. Teknologi informasi telah memberi peluang yang sangat intensif dan strategis dalam kehidupan modern, termasuk dalam mengenal sejarah dan lingkungan kita.

Kondisi yang agak mirip juga terjadi dalam pembelajaran sejarah. Kita sering lebih kenal dan tahu banyak tokoh perjuangan di level nasional, bahkan dapat menjelaskan peristiwa sejarah dunia dengan baik. Kadang kita sering gagap dan kurang mengenal peristiwa sejarah yang terjadi di level lokal. Banyak di antara sejarawan atau guru sejarah di Trenggalek, Tulungagung dan Blitar yang mengenal Romo Mangun, pendeta yang mendampingi masyarakat di Kali Code Yogyakarta. Namun 
banyak yang kurang kenal siapa Romo Logano. Romo Logano adalah tokoh yang mengenalkan dan mendampingi masyarakat pesisir Selatan Blitar, Tulungagung dan Trenggalek menjadi nelayan. Kini namanya digunakan sebagai nama salah satu penginapan di pantai Prigi Trenggalek. Demikian pula banyak sejarawan dan guru sejarah di Malang yang kenal dan memahami sepak terjang perjuangan Jenderal Soedirman dalam Revolusi Nasional, namun banyak yang kurang kenal dan paham sepak terjang Hamid Roesdi, salah satu tokoh perjuangan pada era Revolusi Nasional di wilayah Malang Raya. Banyak diantara kita yang tahu tempat-tempat wisata yang jauh dari lingungan kita dan kurang tahu lokasi wisata di sekitar kita. Dan, untungnya dengan meningkatnya wisata sebagai suatu bagian industri kreatif memberi dampak positif bagi penulisan sejarah lokal untuk tujuan wisata.

Kondisi ini tidak harus kita sikapi secara berlebihan. Kita tidak harus berpikir dikotomis dengan mempertentangkan antara yang lokal dengan yang nasional atau dunia. Kurang relevan lagi mendikotomikan antara sejarah sebagai suatu yang bersifat ideografis, yang khusus, dengan ilmu lain yang bersifat nomotetik, yang umum. Pendekatan keilmuan yang bersifat interdisipliner hingga transdipslipiner lebih holistik dan mendalam dalam mendeskripsikan suatu topik, termasuk topik dalam sejarah lokal.

Memang ada sebagian sejarawan yang terlalu asyik mendeskripsikan situs bangunan bersejarah dengan begitu detail sebagai bagian dari sejarah lokal. Mereka lupa atau abai dengan bagaimana proses pembangunan situs tersebut terjadi. Akibatnya, meminjam konsep "pascakolonialisme" (Loomba, 2000:15) mereka abai dengan proses eksploitasi, diskriminasi dan hegemoni yang dilakukan oleh kelompok tertentu dan kemudian tanpa sadar mengagumi "penanda" sang penakluk atau penjajah. Oleh Paulo Fraire sikap tersebut dapat dikategorikan sebagai indicator dari kesadaran naif. Mereka hidup dalam dualitas dimana menjadi itu identik dengan mengagumi dan menyerupai. Maksudnya mengagumi penjajah dan menyerupai sang penindas. Dampak ikutannya tanpa sadar adalah ikut melestarikan mental inferioritas masyarakat pribumi yang seolah tidak memiliki prestasi apapun. Ketimpangan kekuasaan yang relevan dengan topik yang dibahas tidak diungkapkan.

Dalam konteks semacam ini, pendapat Heidegger yang menyatakan bahwa sejarah bukan sekedar apa yang terjadi di masa lampau (Historie) melainkan juga suatu proses yang sedang berlangsung, sejarah yang hidup, (Geschichte) patut kita pertimbangkan dalam mempelajari dan mengembangkan sejarah lokal. Khususnya yang terkait dengan sejarah lokal dalam proses pembelajaran kita berharap tidak hanya jadi penonton dan penikmat masa lampau melainkan juga potensial menjadi pelaku sejarah di masa kini dan masa depan. Menurut Karl Jaspers tanpa perspektif pada hari depan pandangan kita terhadap masa yang telah lampau bersifat 'selesai' dan 'lengkap' dan itu palsu. Kita akan mudah kehilangan perspektif yang disebutnya "prognostic historical thinking", sesuatu yang akan memberikan pecerahan terhadap orientasi kehidupan ke depan (Jaspers, 1961:141) Menurut Soedjatmoko (1984:15), "Pandangan kita mengenai sejarah, mempunyai pengaruh yang tegas atas penghadapan bangsa Indonesia pada hari depannya dan dengan demikian, atas nasib bangsa dan negara kita". Untuk menjaga dimensi keindonesiaan di masa depan, dimana wilayah dan kebudayaan Indonesia yang beragam, memerlukan penjelasan dan pemahaman yang lebih detail sekaligus beragam sebagai bahan rajutan kebhinekaan, sejarah lokal memiliki arti dan fungsi yang strategis.

Untuk itu dalam tulisan ini, penulis akan lebih fokus bagaimana peluang 
mengembangkan sejarah lokal dalam dimensi perspektif yang dimungkinkan relevan dengan kebutuhan masyarakat ke depan. Tulisan akan membahas sekilas tentang pengertian sejarah lokal, dinamika sejarah lokal yang kemudian dilanjutkan dengan perspektif yang perlu dipertimbangkan dalam kajian sejarah lokal. Berdasarkan tulisan -dan dialog dalam seminar ini, ada harapan agar kita, khususnya peserta didik, memiliki sebuah sikap yang oleh Frederich Nietzsche disebut "suprahistoris". Suatu sikap yang positip terhadap kehidupan, yaitu cara berpikir yang mampu menangkap makna-makna yang melampaui perubahan sejarah. Dalam kondisi ini, termasuk kemungkinan menempatkan sejarah sebagai proses penyembuhan (healing history) terhadap mindset dan konsepsi diri manusia sebagai pelaku sejarah.

\section{SEJARAH LOKAL}

Pengertian sejarah lokal tidak selalu bersifat tunggal. Sejarah lokal memiliki dimensi yang beragam. Dalam buku klasik yang diedit oleh Taufik Abdullah (1985:15), dinyatakan bahwa yang dimaksud sejarah lokal adalah "sejarah dari suatu "tempat", suatu "locality", yang batasannya ditentukan oleh "perjanjian" yang diajukan penulis sejarah". Pengertian ini tidak jauh berbeda dengan apa yang dikemukakan oleh Carol Kammens (2003:ix) yang menyatakan bahwa "local history is the study of the past events, or people or groups, in a given geographic area. The focus of the local history can be the place itself, the people who lived there or events that took place in a particular location".

Pengertian diatas secara konseptual dapat membantu kita untuk membedakan sejarah lokal dengan sejarah daerah. Sebuah peristiwa, baik yang sudah terjadi, sedang terjadi, maupun yang akan terjadi tidak dapat dibatasi secara administratif. Setiap peristiwa terjadi dalam konteks dan ruang tertentu yang kadang sulit dibedakan aspek mana yang diharapkan (intended result) dan aspek mana yang tidak diharapkan (unintended result). Dalam kondisi semacam ini diperlukan suatu suatu "imaginasi sejarah".

Dalam penerapan imaginasi sejarah itulah sejak awal, pemilihan tema atau topik yang akan dikembangkan/diteliti dalam sejarah lokal dapat dipertanyakan. Salah satu pertanyaannya adalah apakah suatu peristiwa yang terjadi pada lokal tertentu itu steril, tidak dipengaruhi ataupun mempengaruhi, peristiwa sejarah di tempat lain. Misal, suatu peristiwa sejarah sosial di suatu masyarakat yang biasa mengadakan "selamatan". Biasanya proses selamatan yang diadakan tidak hanya dipengaruhi oleh peristiwa sebelumnya yang terjadi di lokasi tersebut, melainkan juga dipengaruhi oleh peristiwa yang terjadi di lokasi lain. Demikian pula pola kehidupan maupun bangunan rumah masyarakat pedesaan kontemporer. Ada beberapa rumah yang mencolok dengan gaya arsitektur kontemporer. Ternyata rumah tersebut dapat terbangun dengan adanya warga yang menjadi tenaga kerja di luar negeri.

Kondisi ini membuktikan bahwa sejarah yang terjadi dalam lokasi tertentu bukanlah sesuatu yang terisolasi dari peristiwa yang lebih luas. Michael Lewis (2004:604-605), sejarawan lingkungan di Salisbury University Maryland menyatakan "We are fortune that the methods of environmental history are, literally, grounded and oriented toward local case studies reflecting larger cultural trends or natural situation (culture and nature, of course, used advisedly) ... we have no excuse other than time and our lack of knowledge for not incorporating local history into our enviromental history course".

Peristiwa sejarah tidak ada yang terkucil dari peristiwa yang lebih luas, misalnya tanaman jagung, padi, ketela pohon, makanan 
yang tersedia, tanaman sengon yang kini banyak tumbuh di pedesaan hingga iklim, gaya dan keyakinan hidup bukanlah suatu peristiwa yang tidak terkait dengan dunia luar. Dengan demikian dimensi detail suatu deskripsi yang unik tidak dapat dipahami secara utuh tanpa mengkaitkan aspek lain yang relevan dengan topik yang dibahas. Hal ini perlu ditekankan agar deskripsi yang dikembangkan tidak kehilangan perspektif global atau makro, terutama di era globalisasi saat ini. Namun, harus disadari bahwa peristiwa yang diteliti tetap lebih menekankan pada upaya mendeskripsikan realitas di level lokal secara detail agar dapat menangkap dimensi "emik" dari pelaku sejarahnya. Dimensi luar ikut berpengaruh, tetapi bagaimana masyarakat lokal, pelaku sejarah di level lokal mempersepsikan suatu peristwa sejarah itu yang perlu menjadi fokus utama.

Keterkaitan peristiwa di suatu lokal tertentu dengan di tempat lain kemudian juga diwarnai oleh pelbagai episode peristiwa sejarah yang mendahuluinya. Dampaknya tidak ada sejarah yang bersifat tunggal. Peristiwa sejarah cenderung bersifat "multisiplitas sejarah-sejarah". Misalnya, banyak peristiwa atau peninggalan sejarah di pelbagai belahan Nusantara yang banyak dipengaruhi oleh unsur asing. Pada saat bersamaan jejak-jejak tersebut juga membuktikan bagaimana di setiap lokal juga menunjukkan bagaimana masyarakat lokal mampu memasak, mencernakan dan memproduksi ulang pengaruh asing tersebut. Sejarah sebagai suatu proses maupun sebagai kebudayaan materiil tersebut kemudian tetap dirasakan sebagai perkembangan dari sejarah asli masyarakat yang bersangkutan (Soedjatmoko, 1984-44). Bentuk bangunan masjid dan atau pola ritual penghormatan pada orang yang sudah meninggal sangat diwarnai oleh lapisan lapisan sejarah yang tidak tunggal.

Pada saat yang bersamaan, peristiwa sejarah, terutama yang terkait dengan masyarakat tradisional, peristiwa sejarah juga dikaitkan dengan kekuatan adikodrati, mytos dan sebagainya. "Pengalaman umat manusia tidak disadari sebagai sejarah, melainkan ia dapatkan dan dibekukan di dalam cerita-cerita yang menerangkan hubungan manusia dengan susunan alam yang kosmis, dan dalam ceritacerita yang menjadi ilustrasi mengenai caracara bagaimana manusia sebaiknya menghadapi ujian-ujian di dalam dunia yang fana ini" (Soedjatmoko, 1984:18).

Sejarah lokal yang sering diwarnai oleh mitos (clouded in myth) sering mendorong sejarawan larut dalam anggapan. Maksudnya, peneliti larut dengan anggapan masyarakat lokal dimana peristiwa tersebut dipersepsikan selama ini. Nilai dan praanggapan kultural masyarakat setempat lebih dijadikan referensi dibanding referensi teoretis dan metodologis yang tersedia. Untuk itu pemahaman tentang metodologi dan teori yang relevan dengan topik yang diteliti menjadi sangat diperlukan dalam penelitian sejarah lokal (Abdullah, 1987:3). Peneliti perlu waspada, biasanya dilakukan dengan otokritik, akan kemungkinan menyelinapnya unsur-unsur ahistoris dari topik sejarah yang diteliti sebagai pertimbangan interpretasi. Eksistensi sejarah sebagai ilmu yang logis dan empiris dapat menjadi acuan selama berlangsungnya penelitian dan atau penulisan sejarahnya. Dalam sejarah lokal yang terkait dengan tujuan wisata, dimensi mitos tersebut biasanya dikemas dalam suatu kisah yang menarik dan tidak jarang dijadikan sebagai salah satu ikon.

Dengan pemahaman sejarah lokal diatas memungkinkan penelitian dan penulisan sejarah tidak hanya bersifat deskriptif, melainkan juga dapat dilakukan secara analitis dan reflektif. Penelitian sejarah lokal dengan demikian juga dapat menjadi bagian gerakan "kesadaran diri" sekaligus sarana pengembangan kapasitas belajar bagi peneliti dan pembacanya. Si peneliti perlu membaca sumber-sumber yang relevan dengan topik yang menarik dirinya. Untuk itu 
sejak dalam pemilihan topik perlu dirumuskan tentang apa yang akan diteliti secara serius dan reflektif. Topik yang dipilih memang ada bukti yang dapat dijadikan pijakan awal terjadi pada suatu area atau lokal tertentu. Dengan sumber informasi yang dimiliki kemudian ditentukan apakah topik tersebut lebih layak untuk makalah, penelitian skripsi, tesis atau disertasi atau untuk pengembangan wisata hingga dasar pemekaran wilayah administratif baru.

Dengan pemilihan topik tersebut kemudian ditentukan langkah-langkah dan metode (Syamsuddin, 2007:14-15) yang diperlukan dalam proses pengumpulan data. Bisa diawali dengan membaca literatur lebih lanjut yang relevan kemudian dilanjutkan observasi terhadap situs atau monumen, mencari dokumen yang relevan atau mendukung hingga kemungkinan melakukan wawancara (sejarah lisan) atau menggali tradisi lisan (Vansina, 2014) yang relevan dengan topik yang ditelitinya.

Pelbagai data yang terkumpul kemudian diverifikasi validitas dan reliabilitasnya. Kebiasaan ini dapat memberikan pengaruh positif pada pola pikir yang bersangkutan untuk tidak serba percaya pada informasi yang ada (Kartodirjo,1992:21). Data yang sudah tersaring tersebut kemudian dibingkai dalam suatu kerangka kisah atau ploting cerita. Supaya ploting ceritanya dapat dipertanggungjawabkan perlu didasarkan kerangka pikir atau logika serta interpretasi (yang bisa berdasarkan pada teori yang dianut) yang relevan dengan hasil temuannya. Dalam kondisi semacam ini, peneliti perlu waspada agar tidak terperosok oleh bias konfirmasi (confirmation bias). Sebuah sikap atau kecenderungan yang hanya akan mencari dan menggunakan informasi yang mendukung teori atau tujuan penelitiannya saja yang digunakan. Sementara informasi yang bertentangan tidak digunakan sebagai bahan konstruksi kisahnya.
Untuk sejarah lokal yang ditulis dalam ranah sejarah populer, tentu teori yang digunakan tidak harus diungkapkan secara eksplisit. Data yang terkumpul tidak sekedar dirajut berdasar akal sehat melainkan suatu kerangka pikir yang jelas dan mudah dipahami. Dalam kondisi tersebut, maka proses penulisan sejarah lokal dapat dilakukan secara tematis dan mengalir.

\section{PERISTIWA YANG MENGALIR}

Berangkat dari pemikiran bahwa setiap peristiwa selalu mengalir dan berada/terjadi dalam lokal tertentu, seyogyanya dalam membuat periodisasi dilakukan secara jelas dan fleksibel. Batasan akan ruang lingkup tersebut memungkinkan peneliti dapat membuat rencana dan pelaksanaan penelitian secara mengalir tanpa harus terlalu ketat melaksanakan secara linier. Maksudnya proses interpretasi sudah dapat dilakukan sejak awal penentuan topik dan pengumpulan data. Tatkala data yang berhasil diperoleh tidak sesuai dengan landasan interpretasi yang ada, peneliti harus secara jujur bersedia mengubah dan mencari landasan teori yang lebih cocok atau relevan. Dengan demikian pola pengolahan data dan atau penulisan sejarah sudah dapat dilakukan secara interaktif.

Kondisi ini dapat membiasakan peneliti untuk tidak sekedar berusaha mempelajari, memahami, menguasai dan mendalami topik yang diteliti. Si peneliti juga akan "belajar tentang belajar" yang tidak tidak selalu disadari sebelumnya. Dalam proses menemukan peristiwa atau suasana yang terkait dengan penelitian yang dilakukan ada kemungkinan menemukan pengalaman dan atau penambahan kemampuan belajar (learning capacity). Kemampuan belajar yang terlatih tersebut memungkinkan yang bersangkutan akan mudah memasuki situasi baru yang belum pernah dikenalnya. Proses pelibatan dalam penelitian 
yang penuh makna tersebut memungkinkan seseorang tidak hanya memiliki kompetensi yang siap pakai, melainkan yang paling utama adalah lebih siap untuk belajar dan menjadi pebelajar. Belajar mensitesakan pendapat, menciptakan ide atau karya, dan yang lebih substansial dalam keberhasilan hidup adalah belajar respek pada orang lain. Proses penelitian yang memaksa seseorang berinteraksi dengan orang lain memungkinkan proses belajar social terjadi. Sikap respek akan membantu yang bersangkutan dapat menjalankan proses penelitian berjalan lancar dan memperbaiki mindset dan sikap hidupnya. Kondisi tersebut dapat meningkat menjadi pengembangan dimensi "etis", karena dalam penelitian diperlukan kejujuran sehingga dimensi "moralitas" akan menjadi landasan dan pegangan hidup. Mereka yang memiliki kecakapan sintesis, mencipta, respek dan etis biasanya berhasil menjalani kehidupannya dengan sukses. Hal ini relevan dengan pepatah yang menyatakan, sejarah dapat membuat orang bijak.

Terkait dengan penulisan sejarah lokal, narasi seyogyanya dibuat lebih komunikatif. Tujuannya agar kisah tersebut juga dapat dipahami oleh masyarakat luas, termasuk masyarakat di daerah tersebut. Sebagaimana yang disinggung sebelumnya, penulisan sejarah lokal akhir-akhir ini tidak selalu bertolak dari keprihatinan akademis. Banyak latar penulisan sejarah lokal untuk menjelaskan tujuan wisata. Perkembangan pembangunan sektor wisata dan posisi tujuan wisata yang telah mendominasi pendapatan pelbagai negara memposisikan penulisan sejarah lokal menjadi sesuatu yang menarik dan atraktif. Banyak majalah yang disediakan di transportasi umum, khususnya di kereta api dan pesawat terbang memuat sejarah lokal yang terkait dengan obyek-obyek wisata. Biasanya ditulis oleh jurnalis yang membuat berita investigatif. Laporan mereka ditulis dengan bahasa yang mengalir disertai pelbagai gambar atau foto yang menarik. Tentu potensi ini dapat menjadi lahan baru bagi pengembangan kemasan penulisan sejarah lokal.

Demikian pula penulisan sejarah lokal, -tepatnya sejarah wilayah atau daerah--, yang dikaitkan dengan pemekaran wilayah atau bahkan untuk penegasan identitas suatu wilayah. "Pesanan" penulisan sejarah semacam ini biasanya kurang memberi "keleluasaan" bagi peneliti dalam mengembangkan fokus penelitian dan atau penulisan sejarah lokal. Tetapi, sebagai peneliti yang memiliki integritas, prinsip-prinsip penelitian yang harus berlandaskan data empiris perlu dipertahankan. Tentang deskripsi, interpretasi atau narasi yang berbeda itu hal yang biasa, selama sang peneliti memiliki argumentasi yang relevan dan logis dengan apa yang dikisahkan.

Penulisan sejarah populer sebagaimana dieinggung diatas tidak harus menghilangkan aspek profesionalitas. Sejarah lokal tetap harus dilakukan secara profesional sehingga dimensi promosi tidak menghilangkan data atau peristiwa yang benar-benar terjadi. Peneliti sejarah makin dituntut untuk tidak hanya piawai dalam melakukan penelitian, melainkan juga menyadari bahwa sejarah lokal akan lebih menarik dikerjakan secara interdisipliner dan bahkan transdipliner.

Penelitian dan penulisan sejarah lokal dalam konteks pembelajaran sejarah tentu memiliki aspek yang khas. Pertama, adalah untuk menjadi sarana pembelajaran sejarah yang konstekstual. Penelitian sejarah lokal dapat dikembangkan menjadi penulisan bahan ajar yang berbasis pada daerah yang bersangkutan. Kita sadar bahwa buku-buku teks sejarah yang diterbitkan secara nasional tidak mungkin membahas sejarah lokal secara detail. Untuk mengisi kekurangan tersebut diperlukan sikap aktif pendidik untuk meneliti atau menulis sejarah lokal. Hasil penelitian lokal tersebut kemudian dapat menjadi salah satu bahan pembahasan sejarah yang relevan. 
Pada saat yang bersamaan, peserta didik juga dapat dilatih untuk meneliti sejarah lokal. Dengan mengetahui dan mengalami proses penelitian, peserta didik sejak awal dilatih untuk mencari dan mengelola informasi. Kemudian juga dilatih untuk berpikir kritis. Tidak boleh menerima informasi yang ada begitu saja. Setiap informasi perlu diverifikasi. Konsekuensinya mereka tidak mudah tertipu oleh berita atau informasi yang keliru, termasuk berita hoax. Dari data yang berhasil dikumpulkan dan diverivikasi yang bersangkutan terlatih untuk merekonstruksi sebuah kisah. Disini latihan menggunakan nalar secara logis dan berargumentasi dengan dukungan data empiris membuat mindset atau pola pikirnya berkembang secara positif. Sudah barang tentu, sebagai proses belajar, kita perlu mengingatkan agar mereka juga tidak terlalu cepat mengambil kesimpulan, terutama yang terkait dengan dimensi prognosis. Kewaspadaan terhadap bias melihat masa lalu (hindsight bias) perlu dikemukakan. Maksudnya mereka harus hati-hati akan efek "saya tahu pasti akan seperti ini jadinya" sehingga terlalu cepat meramalkan masa depan.

Hasil penelitian/penulisan sejarah lokal yang mengalir membuat kita semua sadar dalam kehidupan itu selalu terjadi perubahan, termasuk perubahan di tingkat lokal. Sikap manusia terhadap perubahan sangat dipengaruhi oleh cakrawala yang dimiliki. Keunikan sejarah yang ada di lingkungannya juga dapat dipertimbangkan sebagai bagian dari kearifan lokal, sehingga kita dapat juga belajar dari aspek simbolik yang umumnya sarat dengan peristiwa sejarah lokal. Dan dalam dimensi profetik, sejarah lokal yang dikembangkan dan dikemas dalam dimensi pemikiran positif dapat menjadi sarana untuk proses penyembuhan dan pengembangan diri.

Sejarah lokal menjadi salah satu tema sejarah yang menarik baik dalam proses penelitian maupun pembelajaran di level pendidikan dasar, menengah dan perguruan tinggi. Demikian pula penelitian sejarah lokal dalam tataran akademis hingga pemenuhan kebutuhan praktis hingga sejarah populer, membutuhkan keseriusan dan pendalaman dari kita semua untuk mengemas dan mengembangkannya secara profesional.

\section{DAFTAR RUJUKAN}

Abdullah, T. 1985. Di Sekitar Sejarah Lokal di Indonesia. Dalam Taufik Abdullah (ed.). Sejarah Lokal di Indonesia. Yogyakarta: Gadjah Mada University Press

Jaspers,K. 1968. The Origin and Goal of History. New Haven \& London: Yale University Press

Kammen, C.2003. On Doing Local History. In Terry A. Bonhart, Forward to On Doing Local History; Reflections on What Historians Do, Why, and What in Means. California: Altanera.

Kartodirdjo. S. 1992. Pendekatan Ilmu Sosial dalam Metodologi Sejarah. Jakarta: Gramedia

Lewis, M. 2004.Reflections: This Class Will Write a Book: An Experiment in Enviromental History Pedagogy. In Journal of Environmental History Vol. 7. Hal. 604-5.

Loomba, A. 2000. Kolonialisme/Pascakolonialsme. Yogyakarta: Bentang.

Soedjatmoko. 1984. Etika Pembebasan. Jakarta: LP3ES

Syamsuddin,H. 2007. Metodologi Sejarah. Yogyakarta: Ombak.

Vansina, J. 2014. Tradisi Lisan Sebagai Sejarah. Jogyakarta: Ombak. 